\title{
Preparing Engineering Students for Global Workplace Communication: Changing the Japanese Mindsets
}

\author{
http://dx.doi.org/10.3991/ijep.v4i1.3297
}

\author{
A. Danielewicz-Betz and T. Kawaguchi \\ The University of Aizu, Aizuwakamatsu, Japan
}

\begin{abstract}
Preparing engineering students for global workplace is a growing need as engineering schools not only recognize the value of university experience, but also discover that many of their students do not demonstrate the right skills and mindsets for global success. Fresh graduates frequently lack knowledge of other cultures and languages and, most importantly, of how communication works. This paper reports on a comparative, qualitative-quantitative study (of Japanese and international students with varying foreign exposure) conducted in a Japanese engineering and computer science university (with English as a medium of instruction), where internationalization and increase in global awareness are being promoted. The ever-increasing need for global skills in employees calls for a shift in educational focus and job application strategies. We suggest measures to be taken at tertiary education level that should lead to improvement of the communication and other global skills in Japanese graduates.
\end{abstract}

Index Terms - communication and culture, employability, global skills, internationalisation

\section{INTRODUCTION}

Global workplace communication skill is an ability to interact with all sorts of people in various settings. Doing so confidently and without inhibition is, however, not a characteristic inherently present in every person. Although this is not directly related to any culture, yet some cultural determinants can reinforce or hinder the interpersonal competence of a given person. This skill can nevertheless be enhanced to a certain degree, as long as there is motivation to do so, coupled with guidance by good communicators. Engineering graduates who join a global workforce of today need the ability to send and respond to messages from professionals that may differ in language, customs and culture. Cross-cultural communication is also tailored to meet the cultural norms of a specific business culture [1].

There seems to exist a general agreement among researchers and policy makers in tertiary education that graduates are not prepared for the changing global economy and the challenges of global communication in the 21 st century. While continued strong technical skills are implicit, the National Academy of Engineering (NAE) report on Educating the Engineer of 2020 [2] lists "team communication, ethical reasoning, and societal and global contextual analysis skills as well as understanding work strategies" as essential for the technical workforce of 2020. In addition, the authoring organizations identify attributes beyond technical competence, including "crea- tivity, ingenuity, professionalism, and leadership". Recent studies advocate broadening the preparation of engineers further in order to address the need for increased competency in entrepreneurial thinking, creativity and design, as well as cross-disciplinary thinking in a global context.

On the other hand, there is a universal stereotype of an uncommunicative engineering student: a 'geek', a 'nerd', an introverted, technically-minded person. This has spawned rich literature on equipping engineering students with employability skills for the 21 st century professions $[3,4,5,6,7]$. Most of those authors pursue a rather theoretical approach, without postulating any concrete measures to acquire the desired skills, apart from designing new curricula. The engineering students tend to be treated generically and cultural differences are not taken into account. At best, the necessary skills to be acquired are listed but not elaborated on in terms of strategies to achieve a given goal $[8,9,10]$. Some studies do put forward certain measures to enhance engineering students' communicative skills, such as student-centred collaborative learning environment using project-based learning methods and peer assessment [11].

Reference [4], for instance, proposes a more comprehensive approach to engineering education that includes a spectrum of teamwork and non-technical experiences, with the study away experience constituting one of the components of the curriculum. The main reason is that such competences as people skills, personal creativity, and developing own opinions and attitudes via hands-on tasks count increasingly more than mere technical knowledge [2].

Furthermore, as recommended by reference [12]), engineering class design should follow the situative approach that emphasizes linking the educational process directly to real life situations in context. Bringing real world practices into the engineering curriculum through (global) English communication programs will expose the engineering students to a broader vision. This is also what we advocate with our practical speaking video and writing assignments (see the Moodle hyperlinks), including job interview simulations and team.

\section{A. Global graduate skills}

Nowadays, we hear much about global competencies in the context of employment skills:

"A global-ready graduate [is] a person with a grasp of global systems, global issues, the dynamics of how things are interrelated and interconnected in the world, and how society can best address global issues." (Ron Moffatt, 
Director of the San Diego State University International Student Centre; cited in Crawford \& Fink, 2011)

Global workforce needs "the skills to listen, observe and evaluate, analyse, interpret, and relate." (Darla K. Deardorff, Director of Duke University's International Education Administrators Association; ibid.). According to a study by Michigan State University [13), employers value most resourcefulness and adaptability. Globally competent graduates ought to be also equipped with a rather diverse set of skills, including acting on own initiative and being self-reliant, demonstrating enthusiasm, inquisitiveness, and interest in continuous learning, and courage. These are followed by self-confidence, selfcontrol, self-knowledge, positive outlook toward adversity, independence, appreciation of diversity, perseverance, creativity, flexibility, comfort with uncertainty, openmindedness, language and communication skills, assertiveness, and sense of humour. The Michigan State "Recruiting Trends 2005-2006" report [14] identifies "geographic awareness and global understanding" as the primary "new competencies [for job seekers] critical to future success".

\section{B. Global mindset}

Global mindset is often defined as a kind of attitude that combines openness to and awareness of diversity across cultures and markets with an ability to see common patterns. Global employees view cultural and geographic diversity as opportunities to exploit and are prepared to adopt successful practices and ideas independent of their origin. As such, cultivating global mindset is a prerequisite to becoming a global company [15]. Global mindset is a unique multidimensional cognitive construct. Reference [16] defines it as a highly complex structure characterised by articulation of multiple cultural and strategic realities on both global and local levels, and the cognitive ability to mediate and integrate across this multiplicity. Its three complementary aspects are: a) an openness to and awareness of multiple spheres of meaning and action; b) complex representation and articulation of cultural and strategic dynamics; and c) mediation and integration of 'globalised' ideas and actions.

\section{Methodology AND Research Questions}

In our study we carried out an anonymous online survey with 20 Japanese students with no study-abroad experience (see Appendix 1 for the survey questions), as well as an email and Facebook questionnaire survey of 7 Japanese students with recent study-abroad experience and 14 international (ex) students (see Appendix 2). We also video-recorded interviews with the 7 Japanese students mentioned above, before and after their stay abroad (see the questions in Appendix 3). The two focus groups consisted of the 7 Japanese students and 6 international students currently studying at our university. The discussions were centred on the differences between studying at home and host universities and the characteristics of computer science students at our university. We also analysed some recent student assignments submitted in Moodle (a course management system), related to our research questions (with 33 valid answers to tasks 1 and 2; 72 to task 3, and 71 to task 4 - see Appendix 4 for the assignment questions). Furthermore, we made use of the data from study abroad fairs which we started organizing in 2010 in order to promote our study abroad programs and to foster global minds. In those fairs, among others, students share their experience of studying abroad by means of presentations. At the end, the audience is asked to fill out a survey questionnaire. Altogether, we surveyed 201 freshmen students in 2010; 177 in 2011; 204 in 2012, and 240 in 2013 and then compared the results year by year. The purpose of the voluntary questionnaire (an average of 205 students attended the fair in the last 4 years, with over $98 \%$ response rate) is to gather information about the students' degree of familiarity with study abroad programs, self-assessment of mindsets and ability to study abroad, English language skills, and the extent to which existing international exchange activities help respond to students' needs (see Appendix 5 for the selected survey questions).

Our research questions were as follows:

1) What are the global skills characterizing a global mindset that engineering graduates should possess? Are students aware of what they should be striving for?

2) How are internationalization efforts of Japanese companies and universities demonstrated? What role is played by culture?

3) In what ways do study-abroad, exchange programs, teaching techniques, and other measures at our university contribute to changes in Japanese mindsets and acquisition of global skills?

Cultural aspects are seldom included in research publications on engineering education. This paper provides a good rationale for considering these factors, in particular in relation to communication skills. Specifically, we address the (changing) Japanese mindset and its effects on employers, recruitment process, and the engineering education in Japan.

\section{A. Japanese communication style}

Japanese culture is a high context culture [17] with close connections exhibited among group members, sharing a similar, intrinsic knowledge base. Symbols and nonverbal cues are frequently used in communication, with meanings embedded in the situational context. Hence, there is constant guessing involved in assessing how others might feel or what they might want. Due to lack of ethnic diversity, the Japanese all share the same language and customs, with their culture dictating putting other people's feelings and needs first [18].

In the context of classroom learning we observe that Japanese students seldom initiate discussion, ask clarifying questions, or volunteer answers. Reference [19] notes that personal responses are not given before one gains confidence as a performer. Reference [20] writes that "in contrast to the West, ritualised performance in Japan appears to be prerequisite to personal expression". The Japanese students' cultural background does not prepare them to interact in the classroom in the same ways as British, American, and other Western students do. The four main characteristics of Japanese communicative style listed are group-mindedness, consensual decision-making, formalized or ritualized speech-making, and listener responsibility for clear communication. These are contrasted with the Western characteristics of individuality, decision by majority, spontaneous expression of creative or original ideas in public and private interaction, and speaker responsibility for clear communication [20]. 


\section{B. The Japanese mindset and global competition}

The challenges of developing global mindsets have been addressed worldwide, not only in Japan. Educational and industrial organizations appear to lack global leadership competence. In Japan, domestic mindset still tends to prevail, with the characteristic caution and slow process of creating consensus before taking any action, which goes against the nature of global business decisions based on speedy assessment of frequently incomplete information and calculated risks, paired out with embracing change and successfully dealing with diversity. Harmony at all cost is not the solution when occasional failure and confrontation are called for. This does not exclude attention to detail, respect for others, politeness, and other Japanese attributes that, in our opinion, should also be integrated into the global mindset. The Japanese exposed to global business need to learn, however, how to skilfully influence others, how to deal with conflict proactively, assert oneself, and adapt to other's communication styles [21].

The restricted mobility of the Japanese, which is culturally and socially determined, should also be addressed. According to a survey by the Sanno Institute of Management, almost half of the Japanese university graduates in the 2010 academic year said they did not want to work overseas, up $20 \%$ from a similar survey in 2001 [22].

\section{Changes in corporate mindsets}

The unique Japanese recruitment system that makes many students think that securing a job is more important than studying is apparently not working well any more [23]. A considerable number of Japanese employers (64\% according to the 2012 Hays Japan survey) have apparently been undergoing changes in recruitment criteria related to search for those exhibiting global mindset. $82 \%$ of the surveyed companies admitted that the task was extremely or somewhat difficult. The results of the Hays Japan survey (2012) demonstrate that a person with a global mindset 1) possesses advanced foreign language skills (especially English); 2) is interested in and able to adapt to different cultures; 3 ) is flexible in approach to work and able to accommodate a difference of opinion.

Traditionally, companies tend to 'blanket hire' students who still have up to two years at the university and then treat them as 'fresh meat' to be formed and developed accordingly. According to the Recruit Co. spokesperson, Japanese companies are determined to develop strategies for globalization that require finding graduates who are proficient in foreign languages, internationally savvy, and able to communicate effectively [23]. The 'Revitalizing Corporate Japan: A Prescription for Growth' report identifies four global realities confronting the future of Japanese companies, namely the arrival of strong Asian competitors and a new middle class of consumers in Asia; increasing business complexity and market connectivity; new models of innovation based on diverse ideas; and an aging economy. In order to meet those realities, the report suggests four approaches that could transform organizations and allow them to remain successful in today's complex global marketplace, namely embracing diversity; opening up through entrepreneurship to speed innovation; making changes in how employees are trained, compensated, rotated and promoted; and focusing more aggressively on growth strategies, including $M \& A$, direct investment and partnerships [24].
According to Glen S. Fukushima, President and CEO of Airbus Japan KK, education will play a key role in Japan's quest to develop global leadership talent. Along foreign language training, Japanese institutions need to offer training in communication skills, including persuading, debating, and asking concise and meaningful questions in a diverse and global setting. The "three S's reputation" (sleep, smile, and silence) at international conferences has to be shed as well [25].

\section{Prevailing recruitment process and signs of change}

The Japanese recruitment procedure is a very long and tedious process that, on average, consists of 15 stages. Several tests and group interviews promoting collective compliance and 'sameness' are, however, increasingly being questioned by some employers [26]. The jobhunting period (shuukatsu) consumes not only time, but also energy and money. This is because students have no choice but to apply to as many companies as possible since there is no guarantee that they will obtain the desirable job. In addition, all the companies hire during the same, fixed period of time. As becoming a freeter (a person with no regular employment) means stigmatization in Japan, this results in anxiety and uncertainty. Consequently, students sacrifice several months of their university time for wasteful shuukatsu pursuit [27]. The traditional Japanese 'resume' (rirekisho) is more of a personal profile than a way to highlight one's qualifications and professional skills. Most Japanese companies still seek candidates whom they can train in a collective team atmosphere. So fitting into the team, in a broader sense, is an important part of the match.

Certain changes toward transformed and more individual mindsets are, however, under way. "It is true that companies are not hiring as much as they did before. But what we see now is a definite mismatch between job seekers and positions offered by companies" (Keiichi Nerei, manager at Digital Hollywood, a leading digital design technology university). The new trend is for companies to employ young people who not only have computer and design skills, but are also apt in other areas, such as marketing and communication [23].

Sonny Corporation, for instance, has announced that it is looking for open-minded and creative candidates. Japanese mobile carrier Softbank is offering employees a monetary incentive for mastering their English [28]. Hiroshi Mikitani, founder and CEO of Rakuten Inc., the largest e-commerce company in Japan and one of the largest in the world, has introduced English as the only company language to ensure Rakuten's position as a global leader. Three out of six senior executives in this engineering organization are non-Japanese and the company now recruits its talent from around the world (City Gate Language Service, 2012). Further examples of good practices come from Kubota Corporation, Itochu Corporation, Yahoo Design, and Sanko Gosei [29].

This testifies to the fact that Japanese companies are developing strategies for globalization, looking for graduates who are proficient in foreign languages and are internationally savvy and able to communicate effectively. The preference is for graduates who can contribute 'something special' to the company business [23].

Toyota Motor Corporation, Japan's leading automaker, has revived its programme that includes sending young employees as 'recruiters' to their alma maters to meet 
students and brief them about the reality of the competitive auto industry. Japanese industry has also started recruiting internationally, especially in Asia (e.g. from top universities in China). Consequently, the Japanese graduates have to increasingly face foreign competition when looking for jobs. Moreover, growing graduate unemployment may trigger a search for new career paths such as entrepreneurship and self-employment. Sony Corporation also actively seeks recruitment of foreign graduates, which should increase to $30 \%$ of new hires in 2013 (up from $4 \%$ in 2010). Other changes in Japanese recruitment practices include varying numbers of new employees, extending the recruitment schedule, and dealing with staff turnover issues [30].

\section{E. Competitive engineering and corporate skills}

In Japan, employability is defined as "skills that enable worker mobility" and "skills that are demonstrated in a company that enable a worker to be employed on a continuous basis" [31]. The idea of "employability skills" replacing "work skills" was initiated by the Special Educational Committee of the Japan Federation of Employers' Association. As mentioned before, Japanese employers tend not to expect job readiness from fresh graduates but look for development potential, placing importance on continuous in-house training programmes [32]. Since 2000, a practical industrialized curriculum in engineering has followed the Japanese Accreditation Board for Entrepreneurship's recommendations, pursuing such skills as critical, innovative and analytical thinking, identification of business opportunities, establishment of good rapport with colleagues to accomplish the organization's goals; working independently; high sense of duty and responsibility, respecting the actions and beliefs of one's colleagues, as well as adaptability to change and challenges in the workplace. The skill that seems to be missing, however, is that of cultural competence. Spreading crosscultural awareness is not usually promoted, both in university and in-company training seminars and workshops.

Reference [33] found out, in study on Japanese industry employers, that communication skills, responsibility, and initiative are among most required personal qualities, as further discussed by references [34] and [35]. Table 1 depicts the engineering students' perception of the important personal qualities, as surveyed by reference [33], indicating that student assessment of employability skills does not differ considerably from the employers' requirements.

TABLE I.

ENGINEERING STUDENTS' PERCEPTIONS OF EMPLOYABILITY CHARACTERISTICS

\begin{tabular}{|c|l|l|l|}
\hline & \multicolumn{1}{|c|}{ Personal skills } & \multicolumn{1}{c|}{ Attitudes } & \multicolumn{1}{c|}{ Traits } \\
\hline 1 & Communication skills & Responsibility & A balanced personality \\
\hline 2 & Problem-solving skills & $\begin{array}{l}\text { Cooperation } \\
\text { (Work in team) }\end{array}$ & Initiative \\
\hline 3 & Goal-setting skills & $\begin{array}{l}\text { Desire for } \\
\text { challenge }\end{array}$ & Flexibility \\
\hline 4 & $\begin{array}{l}\text { Personal presentation } \\
\text { skills }\end{array}$ & Vitality & Sincerity \\
\hline 5 & Visioning skills & Curiosity & Creativity \\
\hline 6 & IT and computer skills & Ambition & Individuality \\
\hline 7 & Leadership skills & Optimism & Sensitivity \\
\hline 8 & Self-assessment skills & & Entrepreneurial mind \\
\hline
\end{tabular}

Source: Nguyen, Yoshinari and Shigeji (2005)
As for the key skills expected by Western employers, a number of surveys were undertaken by Microsoft, Target Jobs, the BBC, Prospects, NACE International, AGR and other organizations, with the following set of competencies emerging: verbal communication, teamwork, commercial awareness, analytical and investigating skills, initiative and self-motivation, drive, written communication, planning and organizing, flexibility, time management, confidence and independence; as well as 'global skills' defined as "ability to speak and understand other languages, appreciation of other cultures, and working abroad" [34].

Reference [10], on the other hand, specifies a set of skills for engineering graduates that are of non-technical nature. New engineering employees are expected to be good team players, exhibiting such skills as written and oral communication, presentation and selling, understanding of economics, business and travel etiquette, managing without authority, and leadership with a global view.

As for the role of English as a global engineering skill, globalization directly influences industry's needs; thus a global engineer must be able to easily cross national and cultural boundaries. This in turn should be reflected in engineering education as a common code for international communication in the field is required [36]. English communication encompasses almost all aspects of the engineering profession nowadays: from marketing to manufacturing, from quality assurance to post-sale maintenance $[37,38]$.

\section{$F$. Internationalization efforts of Japanese university}

In Japan, there are almost three million students enrolled in over 700 universities and four-year colleges, which makes it the second largest higher educational system in the developed world. However, Japanese universities are considered the weakest component in the national educational system. Many Japanese students are said to look at their university time from a more social than academic perspective, with professors demanding relatively little of them. Frequently the focus is placed on job hunting and not on studying. Graduate education in Japan appears underdeveloped when compared to Europe and the United States, although, in response to increased demand related to globalization, Japanese graduate enrolments have increased by approximately one third since the mid-1990s [39].

As reported by reference [40], in Japan, the internationalisation of higher education has traditionally focused on international student mobility. New policies such as the "skilled migration approach" that promotes employment of international graduates ('brain gain' from overseas) have emerged, with some private institutions aggressively recruiting international students mainly from China (revenue-generating approach). In addition, international university rankings have become part of internationalization strategies for increasing global competitiveness.

The internalization efforts are further motivated by the fact that China took over from Japan as the leading source of international students in 1999/00, before being overtaken by India in 2001/02, and then regaining the reigns in $2009 / 10$. Japanese enrolments have plunged from a peak of just over 47,100 in $1997 / 98$ to less than 20,000 in $2011 / 12$ [41]. 
So what forces play a major role in globalising the Japanese mindset? First of all, the government has to empower companies and universities to train students accordingly. Some companies' policies are still, however, very traditional and conservative. In order to nurture global attitudes in students, the government, industry, and universities must pursue a clear and unified policy regarding what they agree to be 'global mind' and provide appropriate guidelines for the job-hunting process.

\section{G. Current university measures in Japan}

Japanese universities have acknowledged the importance of English in engineering education. The 2009 Project for Establishing Core Universities for Internationalization (Global 30) was announced with the objective to strengthen the international competitiveness of Japanese higher education and to offer educational standards that would appeal to foreign students. One of 30 universities is Nagoya University that aims at transforming itself into a "university of the world" [42].

International degree courses, such as International Mechanical and Aerospace Engineering Graduate Course, are also taught at Tohoku University, with almost all classes offered in English since October 2010 [43]. Yokohama National University offers a Creative-City Studies (YCCS) in which the students are expected to develop key skills for global leaders such as multilingual and crosscultural communication, teamwork, leadership, project planning and organizing on the top of acquiring professional knowledge in their major subjects [43].

The International School of Engineering at Kyushu University focuses on efforts to cultivate engineers who can contribute to society's sustainable development. Moreover, the school develops graduates with a global perspective aiming at improvement of industrial and scientific technologies [44].

\section{H. Study abroad programmes at Japanese university}

As reference [4] Miller (2007) points out, study abroad programs provide an important educational component in preparing future engineers for the global challenges. When well conceived and implemented, such programs facilitate the ability to work in diverse teams, with exposure to sometimes very different cultural values, attitudes, and 'ways of doing things'. Students are also made aware of the opportunities and challenges facing engineers in other regions of the world. Table II illustrates some concrete internationalization endeavours undertaken by Japanese universities.

The types of study-abroad programs offered by Japanese universities are illustrated in Fig. 1.

Those programs can be divided into academic, cultural, as well as research and hands-on programs. Generally speaking, since engineering students' curricula are very tight, students prefer research-based activities.

\section{Study abroad and exchange program at our university}

Our university's study abroad programs offer students an opportunity for educational development and research at international partner universities. They aim at creating future global engineers and at enhancing the university's global competitiveness. Encouraging students to study abroad also contributes to bringing in a broader view on research and education to the university and raising the standards, which have in the meantime become international.

The closest exchange agreement partner is RoseHulman Institute of Technology (RHIT), Indiana, USA. The selected students attend classes there and gain valuable cross-cultural experience. The program ranges from 3 weeks to one year, whereby, depending on the duration, students may do some research and earn course credits there. Students can apply for financial support only once during their enrolment at our university. Upon completion of a given program, they are required to make a presentation on their achievements. As mentioned before, to raise our students' awareness about various possibilities of studying abroad, we organize study abroad fairs on an annual basis. Fig. 2 presents the most frequent responses to the survey question: "Are you interested in going abroad?"

As can be seen, there are numerous factors that negatively affect study abroad decisions.

TABLE II.

INTERNATIONALIZATION EFFORTS OF JAPANESE UNIVERSITIES

\begin{tabular}{|l|l|}
\hline University & Study abroad programmes for Japanese students \\
\hline Waseda Univ. & $\begin{array}{l}\text { Four-year special study-abroad program (selects 15 } \\
\text { students, and subsidizes travel expenses) }\end{array}$ \\
\hline $\begin{array}{l}\text { Hitotsubashi } \\
\text { Univ. }\end{array}$ & $\begin{array}{l}\text { One-year program to Oxford Univ. 3,500,000 yen } \\
\text { maximum financial support }\end{array}$ \\
\hline Meiji Univ. & $\begin{array}{l}\text { Study-abroad preparation is offered with credits } \\
\text { (including talks by guest speakers from industry) }\end{array}$ \\
\hline Keio Univ. & $\begin{array}{l}\text { Introduced new scholarship types, has a special US } \\
\text { study-abroad coordinator in place }\end{array}$ \\
\hline Reitaku Univ. & $\begin{array}{l}\text { Provision of 300,000 yen (maximum) scholarship } \\
\text { led to fourfold increase in applicants (190 appli- } \\
\text { cants) }\end{array}$ \\
\hline $\begin{array}{l}\text { Ritsumeikan } \\
\text { Univ. }\end{array}$ & $\begin{array}{l}\text { Offers a special program, in collaboration with } \\
\text { Korea and China }\end{array}$ \\
\hline Doshisha Univ. & $\begin{array}{l}\text { Offers 300,000 yen scholarship for 4 different } \\
\text { program (470 applicants) }\end{array}$ \\
\hline Univ. of Kyoto & $\begin{array}{l}\text { Implemented the International English Language } \\
\text { Testing System (IELTS) }\end{array}$ \\
\hline
\end{tabular}

Source: The Nikkei Newspaper, May 1, 2012

- Typical Study Abroad Programs
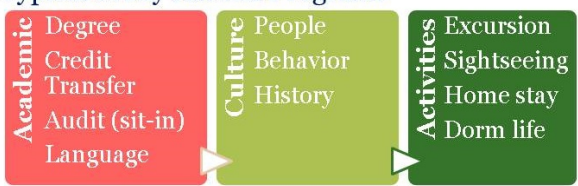

- Study Abroad Programs for Engineering Students
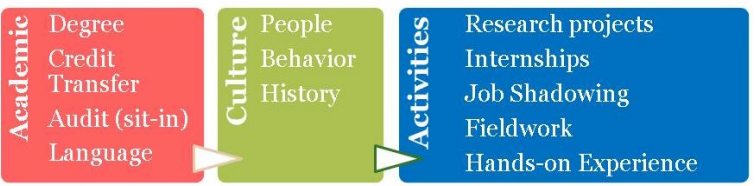

Figure 1. Types of study abroad program

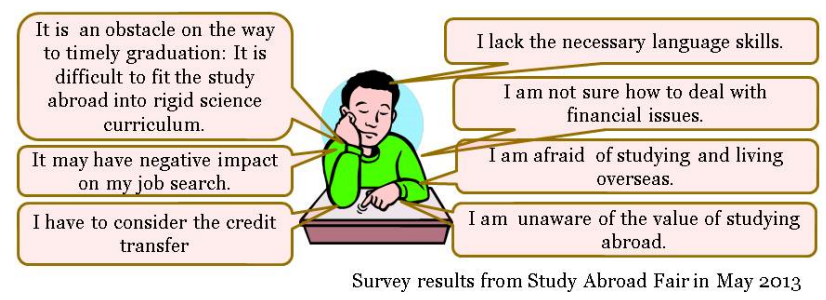

Figure 2. Students' awareness about studying abroad 
Moreover, our surveys elicited open-ended responses testifying to the fact that faculty's advice and opinions play a strong role in students' decisions against going abroad. Based on the comments of sophomore and senior students participating in the study abroad fairs (non-first semester students interested in going abroad also attend those fairs), we list some collective faculty and staff members' perceptions regarding the study abroad program (see Appendix 5):

-It delays students' research progress and graduation (reinforcement of the Japanese belief of following a 'straight path' of studying and job hunting in a timely manner, without collecting extra-curricular experience);

- Matching courses and transferring credits is a timeconsuming process;

- Students will have an opportunity to work overseas without the study abroad experience anyway.

This shows that faculty often discourage students from going abroad, thus displaying 'non-global mindsets'. Despite the reservations mentioned above, the number of students participating in the study-abroad program in the USA has been continuously growing, as illustrated by Fig. 3 .

The number of international students from RHIT coming over to Japan has also been steadily rising (see Fig. 4).

Figures 5-12 depict the results of our comparative analysis of the study abroad fair survey responses from 20102013 (see Appendix 5).

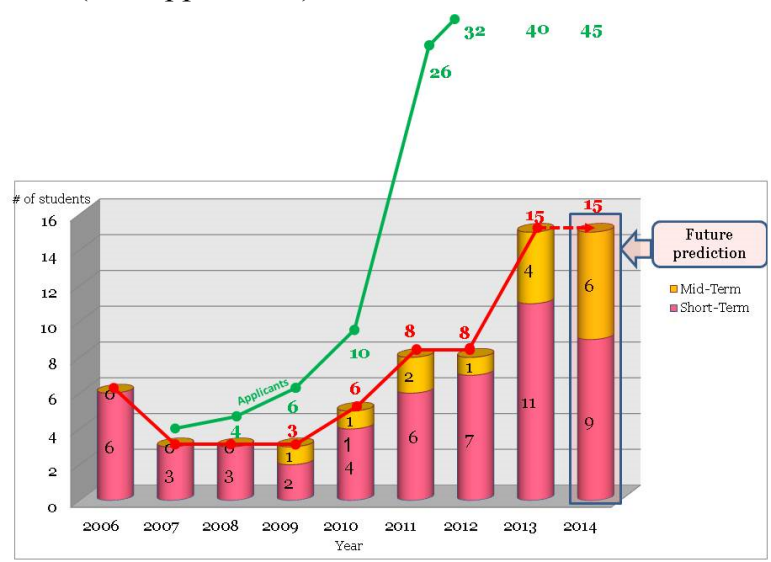

Figure 3. A raising number of UoA Students going to USA

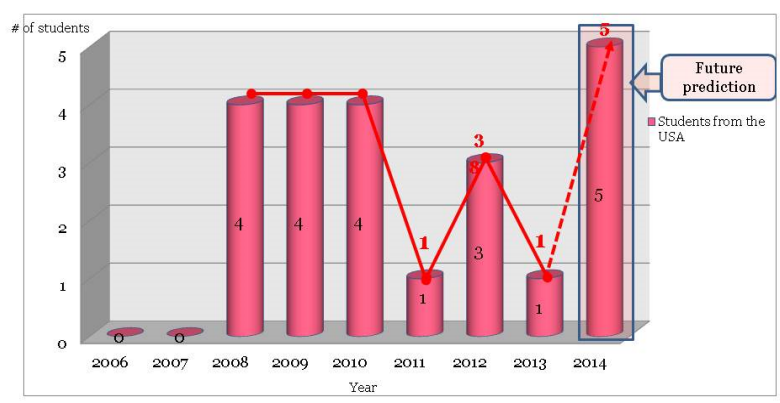

Figure 4. The number of students from USA

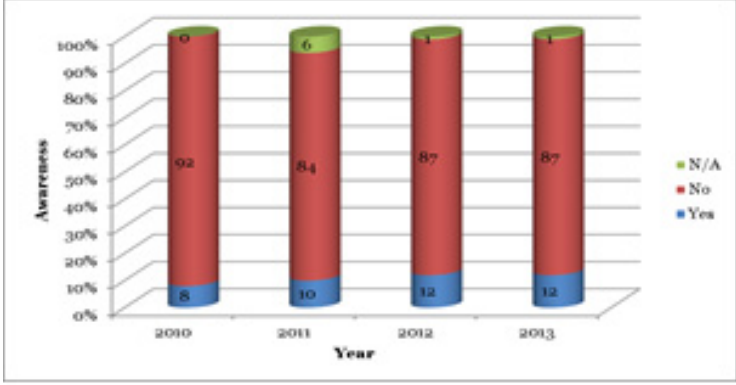

Figure 5. Student self-assessment of English skills

$84-92 \%$ of the respondents are not comfortable using English, with only 8-12\% assessing their English skills positively.

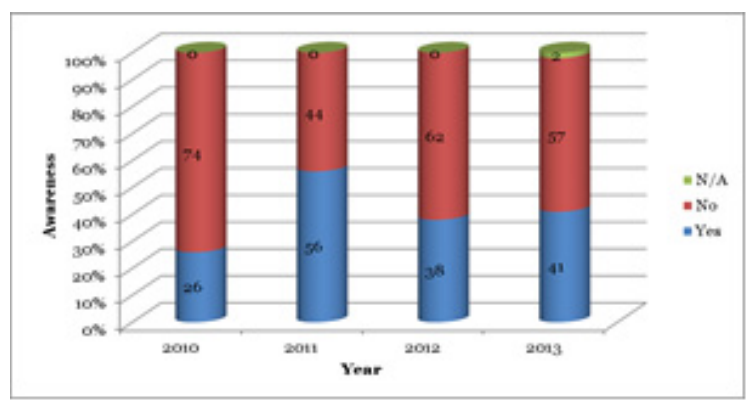

Figure 6. Using English at work

$54-74 \%$ of the respondents are hesitant to work in English language environment. Nevertheless, the numbers of positive responses have been increasing.

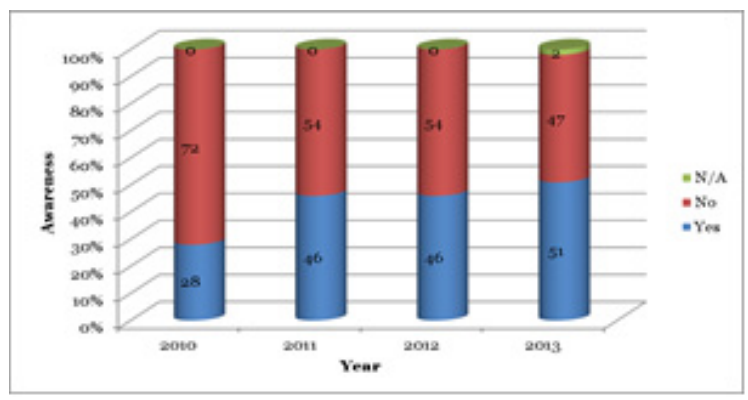

Figure 7. Intention to study abroad

The number of respondents interested in studying abroad has increased from $28 \%$ in 2010 to $51 \%$ in 2013 , which is a positive trend.

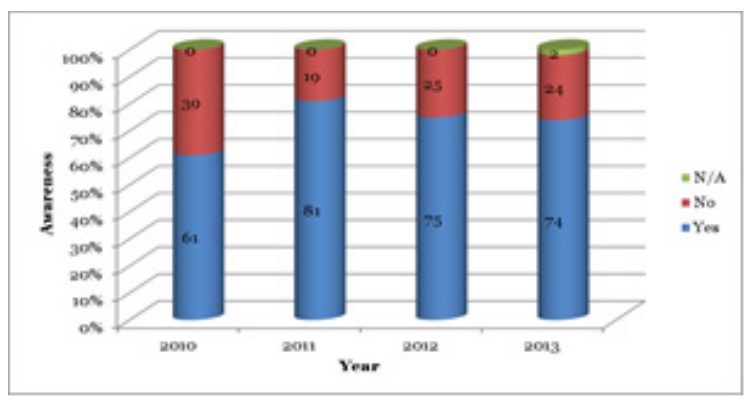

Figure 8. Contact with foreigners

$61-81 \%$ of the respondents wish to have a foreign friend in Japan. 


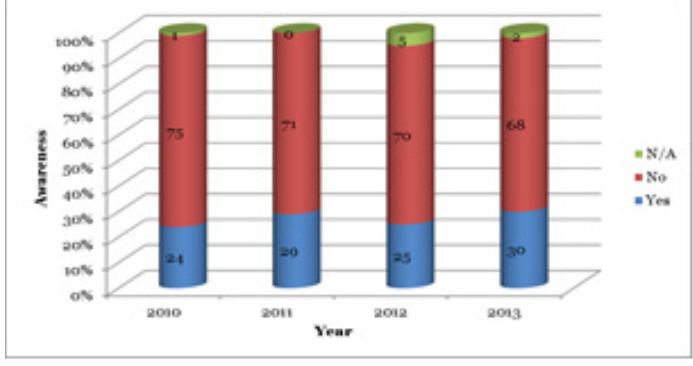

Figure 9. Opportunities to use English in extra-curricular activities

Despite the fact that the majority of respondents are willing to have contact with foreigners, they do not actively seek any opportunities to do so $(68-75 \%$ negative responses).

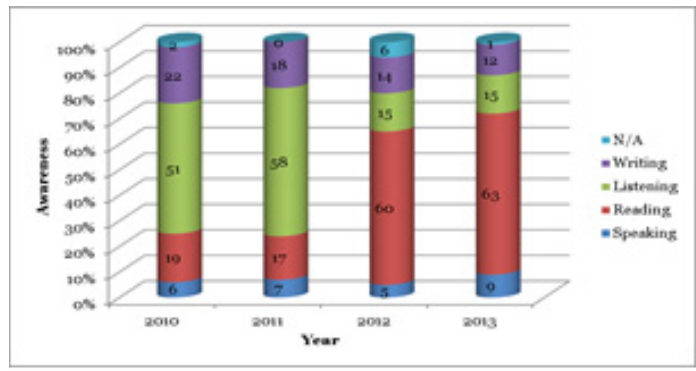

Figure 10. The strongest English skill

As one can see, reading and listening are the strongest skills, reflecting the focus of English education in Japan.

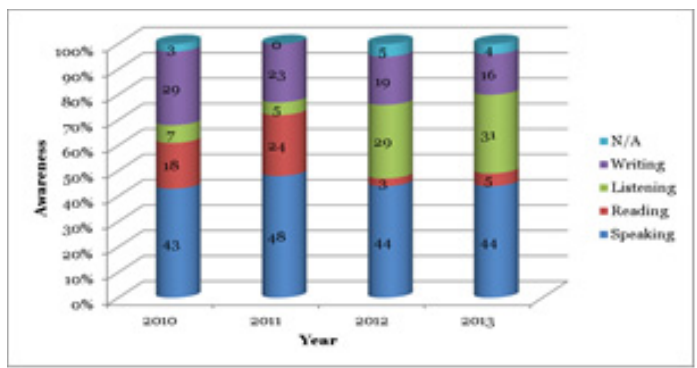

Figure 11. The weakest English skill

Speaking appears to be the weakest skill, which is predictable and reflected in students' classroom performance.

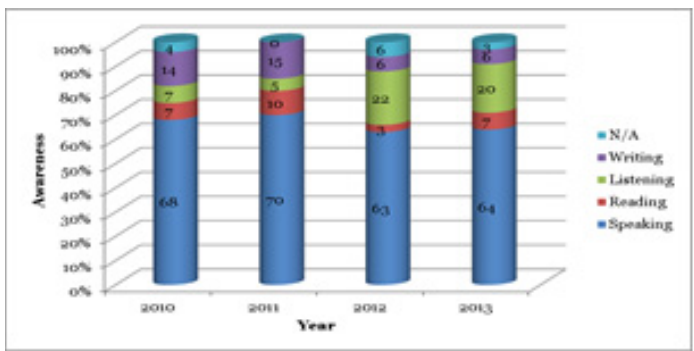

Figure 12. English skills to improve most

Consequently, speaking is clearly the top skill requiring improvement, according to the majority of respondents.

\section{J. Global skills}

In this section we analyse key survey questions (group A and B) and Moodle assignment tasks 1-4 (see Appendix 4) related to selected global skills discussed above.

\section{K. Work experience}

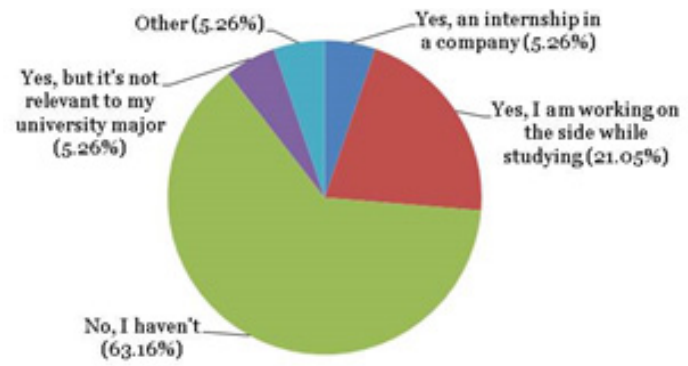

Figure 13. Limited corporate exposure of Japanese students (survey group A)

As can be observed in Fig. 13, the majority of our respondents have had no professional experience, although, provided their computer skills, such as programming are superior, they certainly have opportunities to obtain parttime jobs at a local venture companies, for example.

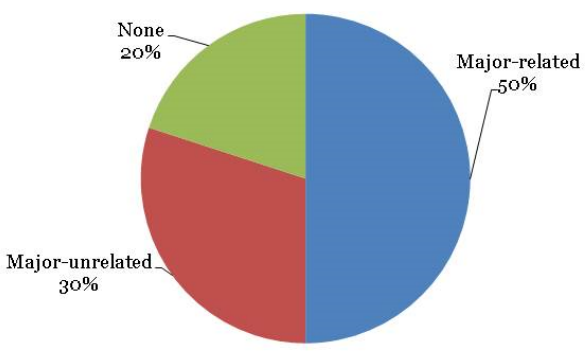

Figure 14. Work experience (survey group B)

Fig. 14 shows that, by contrast, $50 \%$ of the respondents in group B demonstrate work experience related to their major, with $30 \%$ having major non-related work experience.

\section{Future Employer Preference}

This question is related to mobility and global/local orientation of the respondents.

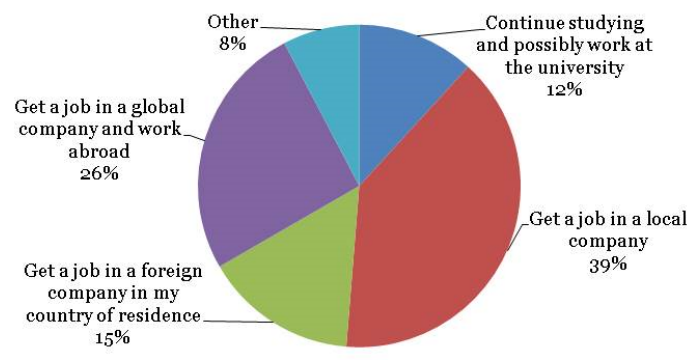

Figure 15. Career plans (survey group A)

As can be seen in Fig. 15, 39\% of the respondents in group A aim at getting a job in a local company, followed by an ambition to work for a global company and/or abroad (15\%). We noticed that many students feel obliged to go back to their hometowns after graduation and to rejoin their families, although they may have developed a more global attitude and, personally, would like to work in a multinational company elsewhere.

Assignment task 4 (see Appendix 4) also revealed that $68 \%$ of sophomore students with no study-abroad experience intend to work for a local company, with $20 \%$ interested in working for a global company in Japan and only $2 \%$ considering a job abroad (see Fig. 16). 


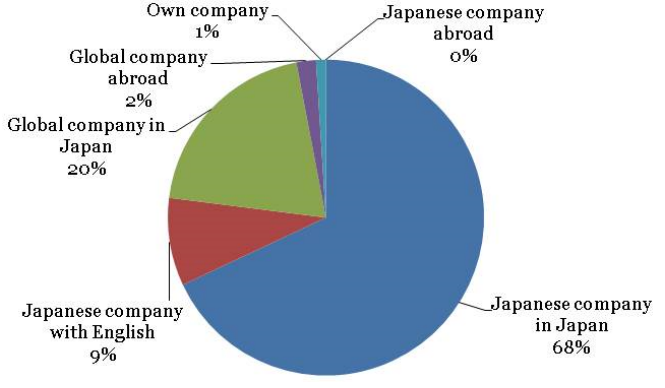

Figure 16. Company type preferences

Figure 16 points to one of many differences between survey groups $\mathrm{A}$ and $\mathrm{B}$, indicating that a significant percentage of both international and study-abroad group respondents either intend to work for a global company abroad $(53 \%)$ or for a foreign company in their home country $(33 \%)$.

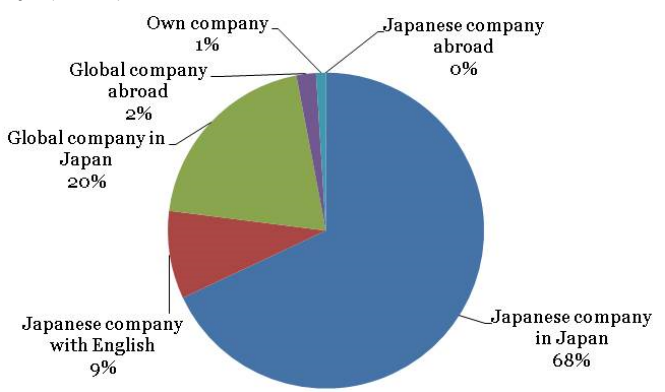

Figure 17. Career plans (survey group B)

\section{Cross-cultural competence}

In survey group A, 3 out of 20 respondents (15\%) offered somehow plausible explanation regarding the concept of cross-cultural competence. The rest openly admitted not knowing what it meant. By contrast, 30\% of group B respondents were able to define the concept, with $40 \%$ being familiar with the term but unable to explain it. So, although cross-cultural competence is one of the crucial global skills nowadays, it seems rather unfamiliar to our respondents on the whole.

\section{N. What are 'global skills'?}

Both the international and Japanese students in group B were asked to name some global competencies they were aware of. We assumed that group A and regular students (those who submitted assignments in Moodle) were not in a position to answer this question.

TABLE III.

GLOBAL SKILLS (SURVEY RESULTS)

\begin{tabular}{|c|l|l|}
\hline Rank & $\begin{array}{c}|c| \\
\text { Global Skill } \\
\text { (International Respondents) }\end{array}$ & $\begin{array}{c}\text { Global Skill } \\
\text { (Japanese Respondents) }\end{array}$ \\
\hline 1 & $\begin{array}{l}\text { Adaptability to new situa- } \\
\text { tions and tasks }\end{array}$ & Communication skills \\
\hline 2 & Team work and team spirit & $\begin{array}{l}\text { Language skills (especially } \\
\text { English) }\end{array}$ \\
\hline 3 & $\begin{array}{l}\text { Language skills (especially } \\
\text { English) }\end{array}$ & $\begin{array}{l}\text { Cultural sensitivity / under- } \\
\text { standing / acceptance by } \\
\text { foreigners }\end{array}$ \\
\hline 4 & $\begin{array}{l}\text { Communication skills (in } \\
\text { English) }\end{array}$ & Adaptation skills \\
\hline 5 & $\begin{array}{l}\text { Cultural sensitivity / } \\
\text { understanding }\end{array}$ & $\begin{array}{l}\text { Professional / IT/ computer } \\
\text { skills }\end{array}$ \\
\hline
\end{tabular}

The 14 international respondents all mentioned the global skills listed in Table 3. As for the Japanese focus group, their set of global skills was shorter, with four skills overlapping.

\section{O. Japanese focus group: Pre-study abroad interviews}

The summary of the video-recorded statements by the Japanese focus group who were interviewed prior to their leave for the USA are shown in Fig. 17.

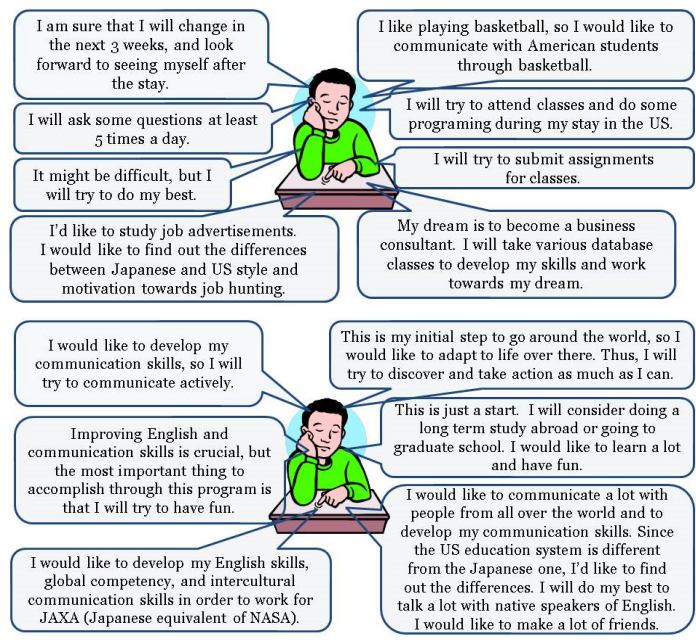

Figure 18. Pre-study abroad interview

\section{P. Post-study abroad interviews}

The main changes that occurred during the stay in the US, as expressed by the Japanese focus group, are summarized in Table 4.

TABLE IV

WHAT CHANGES HAVE YOU UNDERGONE? WHAT LESSONS HAVE YOU LEARNED?

\begin{tabular}{|c|l|}
\hline Mindset & $\begin{array}{l}\text { Broadened, gained cross-cultural perspectives, } \\
\text { put things into perspectives, ability to compare } \\
\text { and see differences (home/host university) }\end{array}$ \\
\hline Career plans & $\begin{array}{l}\text { Graduate studies abroad, work for global compa- } \\
\text { ny, possibly abroad }\end{array}$ \\
\hline Personality & $\begin{array}{l}\text { More critical, open-minded, more confident, } \\
\text { started expressing own opinions, sensitive to } \\
\text { cross-cultural differences }\end{array}$ \\
\hline English skills & $\begin{array}{l}\text { Aware of limited proficiency on the one hand and } \\
\text { of the need to improve on the other, visible } \\
\text { improvement of communicative English }\end{array}$ \\
\hline
\end{tabular}

To sum up the focus group discussions and surveys, we detected clear differences between those who took part in the study abroad programme (survey group B) and the other students who, in most cases, have never travelled abroad (survey group A). Group B members tend to grasp the concept of cross-cultural competence. They mostly have had some job experience, in particular related to their majors. They also wish to either study further abroad or work for a foreign company, possibly abroad. They are more communicative and assertive and their spoken English has improved.

As for the international students, they are able to articulate their strengths better than the Japanese and have definitely heard of "cross-cultural communicative competence" (with $70 \%$ being able to define it, compared to $10 \%$ in group A). They also do not dwell on weaknesses the way Japanese students do (with the most common Japa- 
nese weaknesses named being 'shyness' and inability to communicate). The international focus group members demonstrate some work experience related to their major and speak at least two foreign languages (as opposed to Japanese limited proficiency in English only). They also wish to obtain global exposure by working for a foreign company, preferably abroad.

We observed that students learn many lessons even during a short (three-week) stay abroad. Our focus group members clearly enhanced their communication ability in English and are willing to express their opinions freely. They now exhibit higher self-esteem, are more selfconfident, have curious minds, and, additionally, have changed their professional plans: they wish to pursue graduate studies abroad and/or work for a global company abroad (for a more detailed account of the focus group results see Appendix 6).

\section{Q. Teamwork}

Assignment task 3 (with 72 valid responses) was related to teamwork, which is one of the important global skills as well as a key Japanese employability skill (see Fig. 11). Although the Japanese students were rather critical in selfevaluation, the majority of $55.55 \%$ claimed to be good team players, supporting the claim with arguments and examples (Fig. 10).

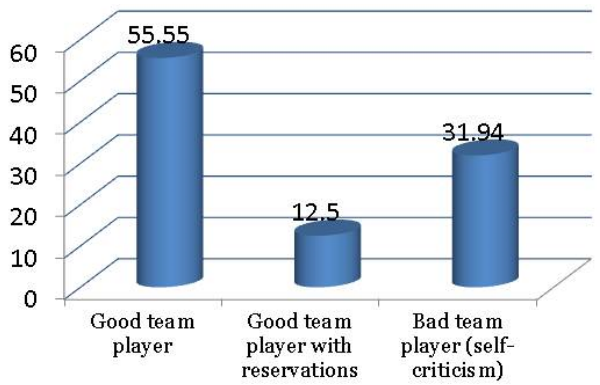

Figure 19. Assessment of own teamwork skill

\section{R. Assessment of main recruitment skills and criteria}

In 2012, the Japanese Association of Corporate Executive Research conducted a large-scale survey to determine the key skills and criteria for successful job candidates in globalizing Japan (see Fig. 19).

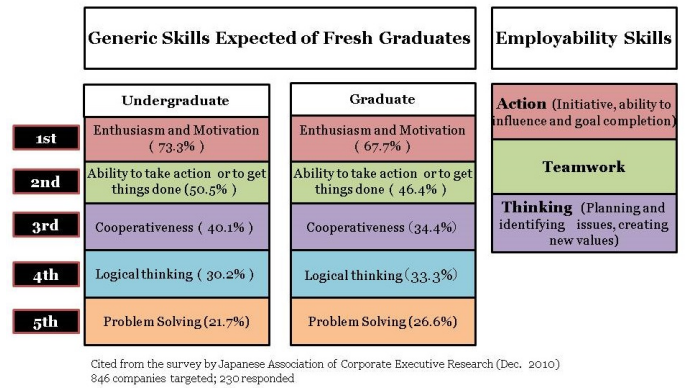

Figure 20. Skills required from globally-minded job candidates

In task 1, we compared the results of that survey with the responses from 33 students in a course assignment (see Appendix 4). The results are summarized in Table 5.
TABLE V.

STUDENTS' RANKING OF SKILLS REQUIRED FROM GLOBAL JOB CANDIDATES

\begin{tabular}{|c|c|c|c|c|c|}
\hline Rank & $\begin{array}{c}\text { Problem } \\
\text { Solving }\end{array}$ & $\begin{array}{c}\text { Ability } \\
\text { to take } \\
\text { action }\end{array}$ & $\begin{array}{c}\text { Logical } \\
\text { thinking }\end{array}$ & $\begin{array}{c}\text { Enthusi- } \\
\text { asm and } \\
\text { motiva- } \\
\text { tion }\end{array}$ & $\begin{array}{c}\text { Coopera- } \\
\text { tion }\end{array}$ \\
\hline $1 \mathrm{st}$ & $15.15 \%$ & $18.18 \%$ & $24.24 \%$ & $18.18 \%$ & $27.27 \%$ \\
\hline $2^{\text {nd }}$ & $15.15 \%$ & $27.27 \%$ & $30.30 \%$ & $18.18 \%$ & $12.12 \%$ \\
\hline $3^{\text {rd }}$ & $27.27 \%$ & $27.27 \%$ & $12.12 \%$ & $21.21 \%$ & $24.24 \%$ \\
\hline $4^{\text {th }}$ & $24.24 \%$ & $21.21 \%$ & $9.09 \%$ & $30.30 \%$ & $12.12 \%$ \\
\hline $5^{\text {th }}$ & $18.18 \%$ & $6.06 \%$ & $24.24 \%$ & $12.12 \%$ & $24.24 \%$ \\
\hline
\end{tabular}

(33 valid responses)

The ranking of those global skills does not correspond in any way with the results of the corporate survey (indicated in the brackets):

1. Cooperation (3);

2. Logical thinking (4);

3. Ability to take action (2);

4. Problem solving (5);

5. Enthusiasm and motivation (1).

The Japanese Association of Corporate Executive Research also determined the key criteria for candidate acceptance by a Japanese company, as summarised in Table 6.

TABLE VI.

STUDENTS’ RANKING OF SKILLS REQUIRED FROM GLOBAL JOB CANDIDATES

\begin{tabular}{|c|c|c|c|}
\hline Criteria & \multicolumn{3}{|c|}{ Order of Priority } \\
\hline & $1^{\text {st }}$ & $2^{\text {nd }}$ & $3^{\text {rd }}$ \\
\hline Result of the interview & 202 & 6 & 3 \\
\hline Result of the written exam & 1 & 67 & 45 \\
\hline Area of expertise & 4 & 26 & 33 \\
\hline Performance at university & 0 & 5 & 19 \\
\hline University reputation & 0 & 7 & 6 \\
\hline
\end{tabular}

Cited from the survey by Japanese Association of Corporative Executive Research (Dec, 2010) 846 companies targeted; 230 responded

It turns out that in order to select successful candidates; most companies look primarily at the results of the final job interview and of a specifically designed written test; only proving the area of expertise to a certain extent. Some companies may still, however, look into the candidate's university performance and the reputation of the university attended.

Again, the corporate survey results were compared with the students' ranking (33 valid responses) in assignment task 2 (see Appendix 4), with the outcome shown in Table 7.

TABLE VII

STUDENTS' RANKING OF KEY CRITERIA FOR SUCCESSFUL CANDIDATE SCREENING

\begin{tabular}{|l|l|l|l|l|l|}
\hline Rank & $\begin{array}{c}\text { Performance } \\
\text { at university }\end{array}$ & $\begin{array}{c}\text { Written exam } \\
\text { results }\end{array}$ & $\begin{array}{c}\text { Area of } \\
\text { expertise }\end{array}$ & $\begin{array}{c}\text { University } \\
\text { reputation }\end{array}$ & $\begin{array}{c}\text { Job inter- } \\
\text { view }\end{array}$ \\
\hline 1 st & $24.24 \%$ & $12.12 \%$ & $21.21 \%$ & $6.06 \%$ & $27.27 \%$ \\
\hline $2^{\text {nd }}$ & $18.18 \%$ & $24.24 \%$ & $24.24 \%$ & $15.15 \%$ & $24.24 \%$ \\
\hline $3^{\text {rd }}$ & $27.27 \%$ & $21.21 \%$ & $33.33 \%$ & $3.03 \%$ & $24.24 \%$ \\
\hline $4^{\text {th }}$ & $24.24 \%$ & $30.30 \%$ & $18.18 \%$ & $12.12 \%$ & $9.09 \%$ \\
\hline $5^{\text {th }}$ & $6.06 \%$ & $12.12 \%$ & $3.03 \%$ & $57.57 \%$ & $15.15 \%$ \\
\hline
\end{tabular}

(33 valid responses) 
The overall ranking looks as follows (with the corporate ranking in brackets):

1. Results of a job interview (1)

2. Area of expertise (3) 3. Performance at university (4)

4. Results of a written exam results (2)

5. University reputation (5)

As can be noted, in this case, the first and last criteria match the company survey order of importance.

\section{S. Enhancing global mindsets}

As mentioned before, cultural environment and faculty have a considerable impact on students' decisions regarding study-abroad time. Globally competent teachers should be in a position to offer extensive exposure to a wide variety of learning tools, as well as effective, handson teaching approaches; coupled with in-depth exposure to foreign cultures and a fresh perspective on education in general:

"... teachers must be qualified to prepare young people for the opportunities and challenges of globalization." - Excerpted from Michael H. Levine, Progressive Policy Institute [13]

Engineering faculty should also be capable of providing insights into changes in administration and educational policies. Therefore, it becomes evident that teachers need to possess the global skills themselves in order to pass them on to students. They should also demonstrate the right kind of attitude to foster global talent.

On another note, some international students subjected to the Japanese job-hunting process reported making negative experience, thus bringing up a reservation whether changing Japanese mindsets is only taking place superficially or whether deeper running changes are under way. Japanese recruiters seem to mistrust foreign applicants, questioning their ability to work in Japanese teams. They look for the Japanese kind of loyalty and compliance, and, above all, 'the right fit', i.e. the 'right' personal characteristics, rather than professional qualifications and skills:

Hiring foreign students is a risk for the company, to some degree. They would rather hire a Japanese person who has little ability than a foreigner because this would mean taking a risk (a Chinese graduate student).

This demonstrates that some traits of the Japanese mindset - running deeply in the Japanese culture and society - cannot be easily changed. These include groupthink, peer pressure, being afraid to stand out or follow an unconventional path. This may include taking longer to graduate due to an internship or a study abroad program and, consequently, ending up with younger fellow students; different career paths, job hopping, venturing out into contracted jobs, etc.

Genuine changes in the Japanese corporate mindsets not just on the surface and for the media - appear not to be yet heading in the global direction. This would namely require commitment to more autonomy and diversity in recruitment criteria and processes; accompanied by openmindedness as demonstrated, e.g., in accepting candidates with the global skills discussed above, but not necessarily willing to spend their whole working lives at one company and making sacrifices that may one day lead to karoshi ("death from overwork").

At our university we work at refining the study abroad program to make it more attractive to students and to ensure that it offers unique experience that cannot be duplicated at the home institution. The key points addressed are English proficiency and major/career relevant content; development of cultural competence; gaining confidence and self-reliance; confrontation with a variety of engineering problems; Project Based Learning (PBL); internships or job shadowing; as well as structured learning and professional experience.

In this way, students will recognize the meaning and intrinsic value of studying abroad. This can only happen through development of strong relationships with partner universities, and provision of sufficient information at the study abroad fairs and various orientation sessions, followed by mentoring and individual guidance. Study abroad programs must be accessible and integrated into the academic curriculum (with credits transferred easily to the home university).

We place considerable significance on pre-and poststudy-abroad orientation sessions so that students can recognize not only the value of overseas experience, but also discover that they may not yet have the knowledge, skills, and mindsets required in order to succeed in today's dynamic globalized economy. Our goal is also to enhance students' awareness of globalization by organising lectures and presentations with corporate presence. Therefore, company executives and global engineers are regularly invited to share their experience (in English) and to illustrate what global citizenship stands for, what states of mind and attitudes are required, and why English is important.

Moreover, we postulate using video 'speaking assignments' as they play a crucial role in assessing students' oral performance and increasing the neglected speaking skill. In this way shyness and group pressure can be overcome and those students who are motivated enough to receive a full grade will finally speak up. We observed that when confronted with a dilemma of either not completing an assignment successfully or approaching an instructor directly; some more ambitious and goaloriented students do seek face-to-face contact or email their queries.

\section{CONCLUSION}

In this paper, we pointed to the necessity of equipping Japanese engineering graduates with global (communicative) skills. We further illustrated competitive engineering and corporate skills from the Japanese and 'Western' points of view, including the role played by English language skills. Having elaborated on the nature of global mindset, we looked at the Japanese domestic mindset from the perspective of the local culture and society. We also attempted to detect changes in Japanese corporate mindset, as reflected in corporate policies and new recruitment criteria. Furthermore, we presented internationalization efforts of Japanese universities, focusing, in particular, on our university and its study-abroad programs and other on and off campus activities. We obtained valuable qualitative and quantitative data from our survey and focus group respondents, especially regarding their mobility, career plans, work and study-abroad experience, as well as familiarity with recruitment criteria, global skills and crosscultural awareness.

We have come to the conclusion that changes in curricula, increased extra-curricular opportunities, and overall 
measures aiming at transforming students' mindsets will not be fully effective unless the mindsets of educators themselves change. Enhancing communicative and other global skills as part of the preparation for global competition requires a high degree of interest and commitment on the part of both faculty and students, followed by willingness to experiment with new approaches; and taking risks along the way [4].

Owing to our internationalization activities and topical course syllabi, as well interactive methods of teaching, we have managed to increase awareness of importance of technical and business English and communicative skills in our students. We also consciously aim at increasing students' speaking, listening, and writing skills (in English). Students taught by us are now applying to participate in study-abroad programs, asking for letters of recommendation and guidance. Willingness to work for a global Japanese company or a foreign company also seems to be on the rise due to our mentoring activities.

We further propose introducing more hands-on projects that combine theoretical engineering knowledge with technical, business, and cross-cultural communication (e.g. a project on cultural customization of company websites). Additionally, project tasks conducted in virtual teams, common at modern workplace, should also be included in engineering syllabi. Moreover, students ought to experience cultural variability by interacting with international students who may have different approaches to completing tasks, for instance, so project teams should reflect cultural diversity [10].

Additionally, focus should be placed on personal and professional strengths rather than weaknesses. So far, there perseveres inability to self-promote. Yet learning how to become more competitive in the global job market does not necessarily have to mean losing one's own cultural identity, and moral and ethical values frequently exhibited by the Japanese. Collectivist attitudes that may advance Japanese engineering students locally, in the face of global competition, need to be coupled with crosscultural competence and globally recognized employability skills.

As for now, fresh graduates still tend to be treated as 'raw material to be formed' [46] - a Japanese approach that does not guarantee global competitiveness. Changes in students' mindsets must, above all, be accompanied by changes in the Japanese corporate perceptions of the value of international education and experience: "They really need to change their mind-set" [47]. Deeper running changes resulting in open-minded and global thinking are crucial - not mere showcasing for the media, but actual practices, starting at the entry level recruitment.

\section{FUTURE WORK}

In future, we intend to conduct a systematic and longitudinal investigation of the study abroad programmes for Japanese engineering students. We will focus on the outcomes in terms of English proficiency, especially in the technical register, as well as on a practical demonstration of communication skills. Moreover, we plan to carry out a comparison of communicative and other global skills (or lack thereof), with respondents coming from Japanese, American, and German engineering universities. We wish to expand this pilot study by obtaining larger data with a higher number of respondents from among study abroad program participants and international students.

\section{REFERENCES}

[1] N. Papa, Define Global Business Communication, eHowmoney.com 2012, Retrieved from http://www.ehow.com/ about 7233094 define-global-business-communication.html

[2] Commitee on the Enginner of 2020, Phase II, Educating the Engineer of 2020: Adapting Enginnering Education to the New Century. The National Academies Press, 2005.

[3] C.M. Vest, NAE Grand Challenges for Enginnering, 2005 Retrieved from http://www.engineeringchallenges.org/cms/7126/ 7639.aspx

[4] R. K. Miller, Beyond Study Abroad: Preparing Engineers for the New Global Economy. Needham, MA: Olin College of Engineering, 2007.

[5] J. Myles, Oral Competency of ESL Technical Students in Workplace Internships. Kingston, Ontario. TESL-EJ, Vol. 13, 2009.

[6] V. Saunders, and K. Zuzel, Evaluating Employability Skills: Employer and Student Perceptions. Bioscience Education eJournal, Vol. 15., 2010.

[7] A. Blom, and H. Saeki, Employability and skill set of newly graduated engineers in India. The IUP Jornal of Soft Skills, Vol 5, pp. $7-50,2012$.

[8] K. Sheppard, P. Dominick, and Z. Aronson, Preparing Engineering Students for the New Business Paradigm of International Teamwork and Global Orientation. International Journal of Engineering Education, Vol. 20, pp. 475-483, 2004.

[9] J. Dulevicius, and L. Nagineviciene, Enginnering Communication. Australia: Global Jornal of Enginnering Education, Vol. 9, 2005

[10] W. O. Craig, Preparing the Engineering Technology Graduate for the Global Marketplace. The Technology Interface Jornal, Vol. 10,2010

[11] J. Requena-Carrion, A student-centered collaborative learning environment for developing communication skills in engineering education. Madrid, Spain: Education Engineering (EDUCON), 2010 IEEE, pp. 783 - 786, 2010

[12] S. Seetha, Communication Skills for Engineers in Global Arena. International Jornal on Airts, Management and Humanities, Vol. 1, pp 1-6, 2012

[13] J. Willard, Global Competency. Sudbury, MA: An Adventure in Teaching. An Expereince in Learning, 2005

[14] Career Service and Placement, C.E.R.I 2005-2006 Recruiting Trends, 2005 Retrieved from http://www.ceri.msu.edu/wpcontent/uploads/2010/03/2005-06-report-final-PDF.pdf

[15] A. Gupta, V. Govindarajan, and H. Wang, Global Mindset. The Quest for Global Dominance, 2008

[16] O. Levy, S Beechler, S. Taylor, and N.A. Boyabigiller, What we talk about when we talk about 'global mindset': Managerial cognition in multinational corporations. Journal of International Business Studies, Vol. 38, pp 231-258, 2007 http://dx.doi.org/10.1057/palgrave.jibs.8400265

[17] G. Hofstede, Culture's Consequences: Comparing Values, Behaviors, Institutions and Organizations Across Nations. Thousand Oaks, CA: Sage Publications, 2001

[18] H. Yamakuse, Dealing with the Japanese: Why Things Go Wrong, and How to Make Things Right. Stone Bridge Press, 2009

[19] M. White, Elementary Schools: Harmony and Cooperation, in M. White (ed.) The Japanese Educational Challenge: A Commitment to Children. Kodansha International: Tokyo, 1987

[20] F. Anderson, The Enigma of the College Classroom: Nails that Don't Stick Up. In P. Wadden (Ed.), A Handbook for Teaching English at Japanese Colleges, pp. 101-110. New York: Oxford University Press, 1993

[21] M. Shell, Towards a Global Mindset, 2011 Retrieved from http://japannvc.com/2011/02/13/towards-a-global-mindset/

[22] S. Kakuchi, JAPAN: Grim job prospects lead to skills rethink, 2011 Retrieved from University World News: http://www.universityworldnews.com/article.php?story=20110122 $\underline{08500378}$ 
[23] S. Knight, Japan's unique recruitment system no longer working, 2012 Retrieved from http://ajw.asahi.com/article/economy/ business/AJ201202090014

[24] S. Khallash, Japanese Firms Must Transform Talent to Grow Globally 2012, Retrieved from http://globaltalentstrategy.com/en/ article/japanese-firms-must-transform-talent-to-grow-globally-314

[25] G. Fukushima, Strategy and Globalization in Japan's Future": Globis International School's First Anniversary Seminar 2008, Retrieved from http://www.globis.jp/372?print=true

[26] L. Melfi, "Job hunting in Japan - What is the general flow of job application?", 2012, Retrieved from http://lastsecret.net/ nadeshiko/article_application.html

[27] W. Wajaya, Time to Re-consider Japanese Shuukatsu (Jobhunting) System 2013, Retrieved from http://willyyanto.wordpress.com/tag/job-hunting-in-japan/

[28] Agence France Presse, Japan's Softbank Emplyees Get Paid to Master English 2013, Retrieved from http://www.asiaone.com/ A1Business/News/Story/A1Story20130111-394982.html

[29] Ministry of Economy, Trade and Industry, About the Indices to Gauge Japanese Companies on their Level of Internationalizing Human Recources (Internatioanl Indices) 2009, Retrieved from http://www.meti.go.jp/english/policy/economy/human resources/ management.pdf

[30] P. Firkola, Japanese Recruitment Practices: Before and After the Global Financial Crisis. Hokkaido: Economic Jornal of Hokkaido University, Vol. 40, pp. 59-71, 2011.

[31] H. Fujimura, Managing the Development of One's Own Vocational Skills in Japanese Companies. Changing Employment System and Its Implications for Human Resource Development. In Labor Review Japan, vol. 1, pp. 23-44, 2004.

[32] H. Ohashi, Engineering Education In Japan-past and present. Tokyo: in Proceedings of the 9th World Conference on Continuing Engineering Education, pp. 15-20, 2004.

[33] N. Nguyen, Y. Yanagawa, and S. Miyazaki, University education and employment in Japan: Students' perceptions on employment attributes and implications for university education. Quality Assurance in Education, Vol. 13, pp. 202 - 218, 2005. http://dx.doi.org/10.1108/09684880510607945

[34] The University of Kent Careers and Employability Services, What are the top ten skills that employers want? 2013, Retrieved from http://www.kent.ac.uk/careers/sk/top-ten-skills.htm

[35] A. M. Zaharim, Y. Yusoff, M. Omar, M., Mohamed, and A. M. Norhamidi, Engineering employability skills required by employers in Asia. EDUCATION'09 Proceedings of the 6th WSEAS international conference on Engineering education, 2009

[36] M. J. Riemer, English and Communication Skills for the Global Engineer. Global Journal of Engineering Education. Melbourne, VIC, Australia: Global Jornal of Enginnering Education., Vol. 6, 2002

[37] F. Grin, English as economic value: facts and fallacies. World Englishes, Vol. 20, pp. 65-78, 2003. http://dx.doi.org/10.1111/ 1467-971X.00196

[38] P. Hart-Rawung, and L. Li, Globalization and Business Communication: English Communication Skills for Thai Automotive Engineers. Bangkok, Thailand. : Conference of Science, Engineering and Technology, 2008

[39] E. Lucien, Japanese Education. Retrieved from Stanford Program on International and Cross-Cultural Education (SPICE) 2012, Retrieved from http://my1stmooc.blogspot.jp/2012/10/bloggingactivity-8b.html
[40] H. Ota, Dispatches from Japan: Thinking beyond international student mobililty 2012, Retrieved from The Guardian: http://www.guardian.co.uk/higher-educationnetwork/blog/2012/apr/23/japan-international-student-mobility

[41] R. Choudaha, L. Chang, and Y. Kono, International Student Mobility Trends 2013: Towards Responsive Recruitment Strategies. World Education Services, Vol. 26, 2013

[42] International Educational Activity at Nagoya University, The Global 30 Project - Bringing Nagoya University to the World 2013, Retrieved from http://www.nagoya-u.ac.jp/en/inter national/edu-act/g30/

[43] Student Exchange Division at Tohoku University, International Mechanical and Aerospace Engineering Course Graduate Course 2013, Retreived from http://www.fgl.tohoku.ac.jp/?section= graduate-programs\&page $=$ imac

[44] Japan Study Support, University Degree Courses in English 2012, Retrieved from http://www.jpss.jp/en/univ/english/

[45] Degree programmes in English 2012, Retrieved from http://www.isc.kyushu-u.ac.jp/g30/programs-e mechanical.html

[46] R. Norris, Some Thoughts on Classroom Management Problems Faced by Foreign Teachers at Japanese Universities. Fukuoka: Bulletin of Fukuoka International University, No. 12, 2004

[47] H. Tabuse, Young and Global Need Not Apply in Japan 2012, Retrieved from www.nytimes.com/2012/05/30/business/global/asglobal-rivals-gain-ground-corporate-japan-clings-to-cautiousways.html?pagewanted=all\&_r=1\&http://www.nytimes.com/2012 /05/30/business/global/as-global-rivals-gain-ground-corporatejapan-clings-to-cautious-way

\section{AUTHORS}

A. Danielewicz-Betz, Ph.D, is an associate professor in the Centre for Language Research, University of Aizu (email: abetz@u-aizu.ac.jp). Her research interests include Pragmatics, Critical Discourse Analysis, Interdisciplinary Studies (e.g. Forensic Linguistics, Corporate Discourse), Business Ethics, and Management of Higher Education. Previously, she worked for Prince Sultan University, Riyadh, Saudi Arabia and Ludwig-Maximilian University of Munich, Germany. She also is an experienced business consultant and trainer offering customized in-house business English courses and coaching services for multinational companies.

T. Kawaguchi is an associate professor in the Centre for Strategy of International Programs, University of Aizu (e-mail: kawaguch@u-aizu.ac.jp). He is responsible for international affairs and international student support and services. His research interests focus on designing and integrating the study abroad programs with an aim to develop effective educational activities by adopting an intercultural approach, as well as ensuring successful preparation for the professional training and development of global engineers. This includes placing study abroad program administration within the local community and management systems for enhancing international student satisfaction, language assessment, and enrolment management. 


\section{APPENDIX 1}

1) What do you want to do after graduation?

a) Continue studying and possibly work at the university;

b) Get a job in a foreign company in my coun-

try;

c) Get a job in a global company and work abroad;

d) Other (specify).

2) Have you had any work experience?
a) An internship;
b) Working part-time on the side;
c) No, none;
d) Yes, but not relevant to my major. Please

specify.

3. Do you know what 'cross-cultural competence' means? If yes, can you briefly describe the meaning of the concept?

4. What are your strong points? Name at least four.

5 . What are your weak points? Name at least four.

6 . How can you compete with other candidates for a job?

What is your 'competitive advantage'?

\section{APPENDIX 2}

1. What strikes you as different in comparison to what you are familiar with back at your university in the Japanese engineering /CS educational system?

2. What are Japanese engineering/CS students like? Are they in any way remarkably different from the students you know back in your country?

3. How many foreign languages do you speak? Please assess your level(s) of proficiency.

4. Have you had any work experience?
(a) An internship;
b) Working part-time on the side;
c) No, none;
d) Yes, but not relevant to my major. Please specify.

5. What do you want to do after graduation?

a) Continue studying and possibly work at the university;

b) Get a job in a foreign company in my country;

c) Get a job in a global company and work abroad; d) Other (specify).
5. What are your main personal and professional strengths?

6. What are your main personal and professional weaknesses?

7. What global skills that employers expect of graduates can you think of? Name them.

8 . What do you understand by "cross-cultural communicative competence"?

\section{APPENDIX 3}

\section{Pre-departure interview}

1. What kind of goals or objectives do you wish to achieve during your study abroad program?

2. What do you see yourself after three weeks? - This one is not clear (even with where)

\section{Post-stay abroad interview}

1. What kind of goals or objectives have you achieved during your study abroad program?

2. Have you noticed how you changed during your study abroad program?

3. How would you like to apply your study abroad knowledge and experiences in your future career?

\section{APPENDIX 4}

\section{Moodle assignments}

\section{Task 1 (33 respondents)}

Based on the research of Japanese Association of Corporate Executives (Dec. 2010), the following basic skills that fresh graduate should demonstrate have emerged. What do you think was their order of significance? Please rate the skills from 1 (most important) to 5 (least important):

Problem Solving

Ability to take action or to get things done

Logical Thinking

Enthusiasm and Motivation

Cooperativeness

\section{Task 2 (33 respondents)}

What is the order of significance of the top recruitment criteria (what employers take into consideration when deciding which candidate to employ)? Please rate the following factors from 1 (most important) to 5 (least important):

Performance at university 
Result of the written test

Area of expertise

Name and reputation of the university attended

Result of the job interview

\section{Task 3 (72 respondents)}

Can you work in teams? Are you a good team player?

Why yes? Why not? Be honest with yourself.

\section{Task 4 (71 respondents)}

What kind of jobs do you find appealing? Name some companies that you would be interested in working for.

Give an example of an ideal job type/position and explain your choice.

\section{APPENDIX 5}

\section{Survey for Study Abroad Fair and Study Abroad CSIP at UoA Thursday, May 23, 2013}

Thank you very much for participating in study abroad fair, and please response the questions as below that we will use them for our future references.

Student ID :

Name:

[English Skills] Please mark the number which is the most appropriated.
A. I am good at
1. Yes
2. No English
B. I would like to
1. Yes
2. No use English at work
C. I would like to study abroad.
D. I would like to
1. Yes
2. No
have a foreign
1. Yes
2. No friend.
E. I have a chance to communicate in English beside classes.

F. My strongest English skill

G. My weakest English skill

H. English skill that you would like to improve most
3. Listening

Please share with us your questions or concerns regarding the international exchange activities and study abroad e.g. lack of support from university/faculty and staff members, etc.

\section{APPENDIX 6}

\section{Perceived differences between RHIT and UoA}

\section{a) RHIT}

- Different types of assignments

- Faster pace of instruction/learning

- Expressing one's opinions freely

- 'Independence' of mind

- Pair work and team work on assignments

- High motivation

- Students asking questions in class

- Professors asking students questions

- Students providing answers

- Active participation/interaction

- Helpful students

- Shorter class periods

- Balance between study time and entertainment

- Kind and friendly teachers

b) UoA

- Mainly lecture style and listening in class

- Learning slowly, slow progress, slower pace of instruction

- Quiet, passive students

- Distance between faculty - students

- Different attitudes of teachers

- Students unwilling to speak

- Students do not ask questions

- Students are too shy

- Students are not diligent enough; do not take assignment seriously enough

\section{International students}

They generally tried not to be too critical of the host institution, nevertheless, mentioned the following points:

- UoA students are quiet and do not say much

- They are not active in class - they do not raise their hands to ask/answer questions

- They are unable to combine studying with enjoyment

- Their attitude to studying is not good

- They do not engage in interesting activities, but instead play video games all the time, for example 